\title{
Soy isoflavones augment the effect of TRAIL-mediated apoptotic death in prostate cancer cells
}

\author{
EWELINA SZLISZKA and WOJCIECH KROL
}

\begin{abstract}
Department of Microbiology and Immunology, Medical University of Silesia in Katowice, 41808 Zabrze, Poland
\end{abstract}
Received February 7, 2011; Accepted April 14, 2011

DOI: 10.3892/or.2011.1332

\begin{abstract}
Prostate cancer represents an ideal disease for chemopreventive intervention. Genistein, daidzein and equol, the predominant soy isoflavones, have been reported to lower the risk of prostate cancer. Isoflavones exert their chemopreventive properties by affecting apoptosis signalling pathways in cancer cells. Tumour necrosis factor-related apoptosisinducing ligand (TRAIL) is an endogenous anticancer agent that induces apoptosis selectively in tumour cells. Soluble or expressed in immune cells, TRAIL molecules play an important role in immune surveillance and defense mechanisms against tumour cells. However, various types of cancer cells are resistant to TRAIL-mediated apoptosis. We examined the cytotoxic and apoptotic effects of genistein, daidzein and equol in combination with TRAIL in LNCaP cells. Cytotoxicity was measured by MTT and LDH assays. Apoptosis was analyzed by flow cytometry and fluorescence microscopy using Annexin V-FITC. Mitochondrial membrane potential $(\Delta \Psi \mathrm{m})$ was evaluated by fluorescence microscopy using DePsipher staining. Flow cytometry detected the expression of death receptor TRAIL-R1 (DR4) and TRAIL-R2 (DR5) on cell surfaces. The soy isoflavones sensitized TRAIL-resistant prostate cancer cells to apoptotic death. The isoflavones did not alter death receptor expression, but significantly augmented TRAIL-induced disruption of $\Delta \Psi \mathrm{m}$ in the LNCaP cells. We showed for the first time that the chemopreventive effects of soy foods on prostate cancer are associated with isoflavoneinduced support of TRAIL-mediated apoptotic death.
\end{abstract}

\section{Introduction}

Prostate cancer is one of the most commonly diagnosed cancers in men and the second leading cause of cancer-related deaths in the EU and the US (1). Worldwide disparities exist

Correspondence to: Professor Wojciech Krol, Department of Microbiology and Immunology, Medical University of Silesia in Katowice, Jordana 19, 41808 Zabrze, Poland

E-mail: wkrol@sum.edu.pl

Key words: prostate cancer, tumour necrosis factor-related apoptosisinducing ligand, soy isoflavones, apoptosis, chemoprevention between geographic regions with regard to prostate cancer incidence. Although genetic factors are important in the etiology of prostate cancer, diet has been presumed to play a key role in prostate carcinogenesis (2). East Asian populations who consume large amounts of soybean foods have lower rates of prostate cancer compared to those in Western countries (EU, US, Canada) $(3,4)$. The soybean is a species of legume that contains high quantities of isoflavones, including genistein, daidzein and equol, which exhibit preventive effects against prostate cancer (5). Isoflavone intake has been estimated to be $25-50 \mathrm{mg} /$ day in Asian countries. Elevated levels of isoflavones are found in the serum, urine and prostatic fluid of Asian men who consume soy-rich foods (5-7).

Isoflavones possess anticancer and chemopreventive properties (8-10). The characteristic isoflavone structure is a flavone nucleus that is composed of two benzene rings $\mathrm{A}$ and $\mathrm{B}$ linked to a heterocyclic ring $\mathrm{C}$. The benzene ring $\mathrm{B}$ position is the basis for the categorization of the flavonoid class (position 2) and the isoflavonoid class (position 3) (3). Soybeans contain isoflavones in four chemical forms: aglycons, glycosides, acetylglucosides and malonylglucosides. The major aglycons present in soy are daidzein, genistein and equol (Fig. 1). Isoflavones have been reported to lower the risk of developing prostate cancer $(4,5,7,11)$. The use of naturally occurring compounds is becoming increasingly appreciated as an effective strategy in cancer prevention (12-17). Prostate cancer is an ideal disease for chemopreventive intervention due to its long latency, late age of onset, relatively slower rates of growth and progression, high incidence, tumour marker availability, identifiable preneoplastic lesions and risk groups $(18,19)$.

Soy isoflavones exert their chemopreventive effects through multiple molecular mechanisms of action that affect apoptosis signalling pathways in cancer cells $(3,19,20)$. Dietary flavonoids have been found capable of augmenting the apoptotic activity of TRAIL against prostate cancer cells (21-24). The tumour necrosis factor-related apoptosis-inducing ligand (TRAIL), a member of the TNF superfamily, selectively induces apoptosis in cancer cells with no toxicity against normal tissues $(25,26)$. Apoptosis can be triggered by two major mechanisms: the intrinsic pathway that involves mitochondrial dysfunction, and the extrinsic pathway that is associated with the stimulation of death receptors (DRs) located on the cell membrane. The binding of TRAIL to specific death receptors TRAIL-R1 (DR4) and/or TRAIL-R2 (DR5) expressed on the 
cell surface induces the extrinsic apoptotic pathway. The stimulation of DRs initiates programmed cell death by promoting recruitment of the adaptor molecule Fas-associated death domain (FADD), the formation of death inducing signalling complex (DISC) and, the activation of caspase- 8 and subsequent effector caspases. Apoptosis can also be mediated by the intrinsic pathway, with the implication of mitochondrial perturbation and the release of cytochrome $\mathrm{c}$. The link between the extrinsic and intrinsic signalling pathways is formed by the BH3- interacting domain death agonist (Bid) protein, which is activated by caspase-8 (26-29). However, some tumour cells are resistant to TRAIL-induced cytotoxicity (29-31). TRAIL can be expressed on the surface of T lymphocytes, natural killer cells, dendritic cells, neutrophils, monocytes or macrophages and can also be cleaved into a soluble, secreted form. TRAIL plays important roles in immune surveillance and defense mechanisms against tumour cells (32).

Failure to undergo apoptosis has been attributed to the resistance of cancer cells to TRAIL surveillance resulting in tumour development. The expression of the death receptors TRAIL-R1 or TRAIL-R2 and pro-apoptotic or anti-apoptotic proteins in cancer cells are involved in TRAIL resistance (26-31). However, it has been demonstrated that TRAIL-resistant prostate cancer cells can be sensitized by dietary flavonoids. Moreover, enhancement of TRAIL-mediated programmed death in prostate cancer cells by soy isoflavones may support antitumour immune responses. Therefore, we tested the apoptotic and cytotoxic effects of TRAIL in combination with soy isoflavones in prostate cancer cells and investigated the molecular mechanisms by which the compounds overcome TRAIL-resistance in cancer cells. This study demonstrated that augmentation of TRAIL-mediated apoptosis in prostate cancer cells by daidzein, genistein and equol confirms the chemopreventive properties of soy isoflavones.

\section{Materials and methods}

Chemicals and reagents. Daidzein, genistein and equol were obtained from Alexis Biochemicals (San Diego, CA, USA). The isoflavones were dissolved in dimethylsulfoxide (DMSO) to obtain working concentrations. Soluble recombinant human TRAIL (rhsTRAIL) was purchased from PeproTech Inc. (Rocky Hill, NJ, USA). Human recombinant TRAIL-R1/Fc and TRAIL-R2/Fc chimera proteins were obtained from R\&D Systems (Minneapolis, MN, USA).

Cell line and culture. The human hormone-sensitive prostate cancer cell line LNCaP was obtained from the German Collection of Microorganisms and Cell Cultures (DSMZ; Braunschweig, Germany). LNCaP cells were maintained in RPMI-1640 medium with $10 \%$ foetal bovine serum, $4 \mathrm{mM}$ L-glutamine, $100 \mathrm{U} / \mathrm{ml}$ penicillin and $100 \mu \mathrm{g} / \mathrm{ml}$ streptomycin and were grown in monolayer cultures at $37^{\circ} \mathrm{C}$ in $5 \% \mathrm{CO}_{2}$ $(22,33)$. Reagents for the cell culture were purchased from PAA, The Cell Culture Co. (Pasching, Austria).

Cytotoxicity assay. Cytotoxicity was measured by 3-(4,5dimethyl-2-thiazyl)-2,5-diphenyl-2H-tetrazolium bromide (MTT) assay as previously described (34). The MTT assay is

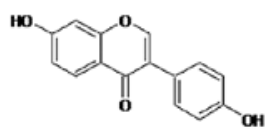

Daidzein

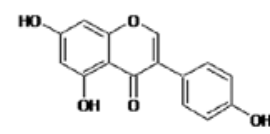

Genistein

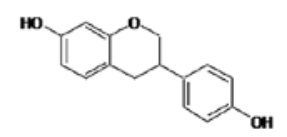

Equol
Figure 1. Chemical structures of the studied soy isoflavones.

based on the cleavage of the tetrazolium salt MTT to the blue formazan dye by viable cells. LNCaP cells $\left(2 \times 10^{5} / \mathrm{ml}\right)$ were seeded for $48 \mathrm{~h}$ before the experiments in 96-well plates. TRAIL (50-200 ng/ml) and/or isoflavones $(50-100 \mu \mathrm{M})$ were added to the cells. After $48 \mathrm{~h}, 20 \mu \mathrm{l}$ of MTT solution $(5 \mathrm{mg} / \mathrm{ml})$ (Sigma Chemical Co., St. Louis, MO, USA) was added to each well for $4 \mathrm{~h}$. The resulting blue formazan crystals were dissolved in DMSO. Controls included native cells and medium alone. The spectrophotometric absorbance at $550 \mathrm{~nm}$ was measured using a microplate reader (ELx 800, Bio-Tek Instruments Inc., Winooski, VT, USA). The percent cytotoxicity was calculated by the formula: Percent cytotoxicity (cell death $)=[1-[$ Absorbance of experimental wells/Absorbance of control wells)] x 100.

Lactate dehydrogenase release assay. Lactate dehydrogenase $(\mathrm{LDH})$ is a stable cytosolic enzyme that is released upon membrane damage in necrotic cells. LDH activity was measured using a commercial cytotoxicity assay kit (Roche Diagnostics $\mathrm{GmbH}$, Mannheim, Germany). LNCaP cells $\left(2 \times 10^{5} / \mathrm{ml}\right)$ were treated with various concentrations of TRAIL $(50-200 \mathrm{ng} / \mathrm{ml})$ and/or isoflavones (50-100 $\mu \mathrm{M})$ for the indicated periods of time. LDH released in culture supernatants is detected with a coupled enzymatic assay, resulting in the conversion of a tetrazolium salt into a red formazan product. The spectrophotometric absorbance at a wavelength of $490 \mathrm{~nm}$ was measured using a microplate reader (35). The maximal release was obtained after treating control cells with $1 \%$ Triton X-100 (Sigma Chemical Co.) for $10 \mathrm{~min}$ at room temperature. The percentage of necrosis was expressed using the formula: (Sample value/Maximal release) x 100.

Detection of apoptosis by flow cytometry. Apoptosis was determined by flow cytometry using the Apoptotest-FITC Kit with Annexin V (Dako, Glostrup, Denmark). LNCaP cells $\left(2 \times 10^{5} / \mathrm{ml}\right)$ were seeded in 24 -well plates for $48 \mathrm{~h}$ and then exposed to TRAIL (50-200 $\mathrm{ng} / \mathrm{ml})$ and/or isoflavones (50-100 $\mu \mathrm{M})$ for $48 \mathrm{~h}$. After this time, the cancer cells were washed twice with PBS (phosphate-buffered saline solution) and resuspended in $1 \mathrm{ml}$ of binding buffer. The cell suspension $(500 \mu \mathrm{l})$ was then incubated with $5 \mu \mathrm{l}$ of Annexin V-FITC and $10 \mu \mathrm{l}$ of propidium iodide (PI) for $10 \mathrm{~min}$ at room temperature in the dark. The population of Annexin V-positive cells was evaluated by flow cytometry (BD FACScan; Becton-Dickinson Immnunocytometry Systems, San Jose, CA, USA) (22-24).

Detection of apoptosis by fluorescence microscopy. Apoptotic cells were quantified by the fluorescence microscopy method using the Apoptotic and Necrotic and Healthy Cell Quantification Kit from Biotium, Inc. (Hayward, CA, USA). LNCaP cells $\left(2.5 \times 10^{5} / \mathrm{ml}\right)$ were seeded for $24 \mathrm{~h}$ before the experiments 

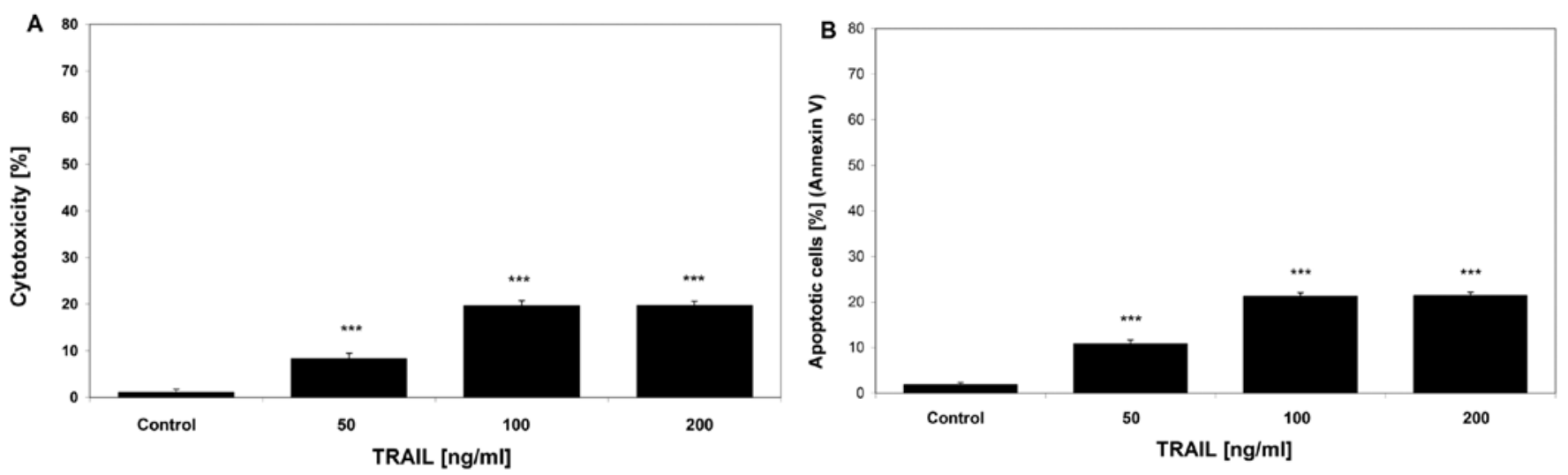

Figure 2. Cytotoxic and apoptotic effects of TRAIL in LNCaP prostate cancer cells. Cells were incubated for $48 \mathrm{~h}$ with TRAIL at concentrations of 50-200 ng/ml. (A) Cytotoxic activity of TRAIL in LNCaP cells. The percentage of dead cells was measured by the MTT cytotoxicity assay. The values represent mean $\pm \mathrm{SD}$ of three independent experiments performed in quadruplicate $(\mathrm{n}=12)\left({ }^{* * * *} \mathrm{P}<0.001\right.$ as compared to control). (B) TRAIL-induced apoptosis in LNCaP cells. Apoptotic cell death was detected by flow cytometry using Annexin V-FITC staining. The values represent the mean \pm SD of three independent experiments performed in duplicate $(n=6){ }^{* * *} \mathrm{P}<0.001$ as compared to control).

in 24-well plates. TRAIL (100 ng/ml) and/or isoflavones $(100 \mu \mathrm{M})$ were added to the cancer cells, and $48 \mathrm{~h}$ later, the cells were washed with PBS and detached from the cell culture wells by trypsin. Next, the LNCaP cells were centrifuged to discard the supernatant, washed with PBS and resuspended in binding buffer (100 $\mu \mathrm{l} / \mathrm{sample})$. A combination of $5 \mu \mathrm{l}$ Annexin V-FITC, $5 \mu 1$ ethidium homodimer III and $5 \mu 1$ Hoechst 33342 solutions were added to each tube. The samples were incubated at room temperature for $15 \mathrm{~min}$ in the dark. After staining, the cancer cells were washed with binding buffer, placed on a glass slide and covered with a glass coverslip. The stained cells were observed under a fluorescence-inverted microscope IX51 (Olympus, Tokyo, Japan) using filter sets for FITC, TRITC and DAPI $(36,37)$. The healthy cells (stained with Hoechst 33342) emitted blue fluorescence, apoptotic cells (stained with Annexin V-FITC and Hoechst 33342) emitted green and blue fluorescence, and necrotic cells (stained with ethidium homodimer III and Hoechst 33342) emitted red and blue fluorescence. The cells were counted, and the apoptotic cells were expressed as a percentage of the total cells.

Evaluation of mitochondrial potential by DePsipher. The DePsipher kit (R\&D Systems) was used to measure the mitochondrial membrane potential in the fluorescence microscopy assay according to the manufacturer's instructions $(24,38)$. LNCaP cells $\left(2 \times 10^{5} / \mathrm{ml}\right)$ were seeded $24 \mathrm{~h}$ before the experiments in 24 -well plates. TRAIL (100 $\mathrm{ng} / \mathrm{ml})$ and/or isoflavones $(100 \mu \mathrm{M})$ were added to the cancer cells, and $48 \mathrm{~h}$ later, the cells were washed with PBS and detached from the cell culture wells by trypsin. The cells were incubated in the dark with DePsipher (5,5',6,6'-tetrachloro-1,1',3,3'-tetraethylbenzimidazolylcarbocyanin iodide) solution at a concentration of $5 \mu \mathrm{g} / \mathrm{ml}$ for $30 \mathrm{~min}$ at $37^{\circ} \mathrm{C}$, washed with reaction buffer with stabilizer, placed on a glass slide and covered with a glass coverslip. The stained cells were observed under a fluorescence-inverted microscope IX51 using filter sets for FITC and TRITC. DePsipher exhibits potential-dependent accumulation in mitochondria, indicated by a fluorescence emission shift from red $(590 \mathrm{~nm})$ to green $(530 \mathrm{~nm})$. In healthy cells, the mitochondria contain red spots following aggregation of the DePsipher within the mitochondria. In cells with a disrupted potential, the dye remains in its monomeric form in the cytoplasm, and uniform green fluorescence appears.

Flow cytometric analysis of death receptor expression on the cell surface of LNCaP cells. The cell surface expression of TRAIL-R1 and TRAIL-R2 receptors in prostate cancer cells was measured by flow cytometry (BD FACScan). LNCaP cells $\left(2 \times 10^{5} / \mathrm{ml}\right)$ were seeded in 24 -well plates for $24 \mathrm{~h}$ and then exposed to isoflavones $(100 \mu \mathrm{M})$ for $48 \mathrm{~h}$. The cells were then harvested using trypsin and EDTA (ethylenediaminetetraacetic acid), washed twice in PBS and resuspended in PBS containing 0.5\% BSA (bovine serum albumin). Cells were incubated with $10 \mu 1$ phycoerythrin-conjugated antiTRAIL-R1 or anti-TRAIL-R2 monoclonal antibodies (R\&D Systems) at $4^{\circ} \mathrm{C}$ for $45 \mathrm{~min}$. After staining, the cancer cells were washed with PBS and analyzed by flow cytometry $(38,39)$. The control consisted of cells in a separate tube treated with phycoerythrin-labelled mouse $\operatorname{Ig}_{1}$ or mouse $\operatorname{IgG}_{2 B}$ (R\&D Systems).

Statistical analysis. The results are expressed as the mean \pm $\mathrm{SD}$ obtained from three independent experiments performed in quadruplicate $(n=12)$ or duplicate $(n=6)$. Statistical significance was evaluated using the Levene or Bartlett $\chi^{2}$ test, followed by analysis of variance (ANOVA). The expression of death receptors was assessed using the Student's t-test. $\mathrm{P}<0.05$ was considered significant.

\section{Results}

Cytotoxic and apoptotic effects of TRAIL in prostate cancer cells. TRAIL induced cytotoxic and apoptotic effects in LNCaP prostate cancer cells in a dose-dependent manner. The cytotoxicity after a 48-h incubation of TRAIL at concentrations ranging from 50 to $200 \mathrm{ng} / \mathrm{ml}$ resulted respectively in cell death from $8.28 \pm 1.18$ to $19.70 \pm 0.93 \%$ (Fig. 2A). The percentage of necrotic cell death of LNCaP cells examined by Apoptest-FITC and the LDH assay was approximately zero. TRAIL-induced apoptosis in the LNCaP cells was 

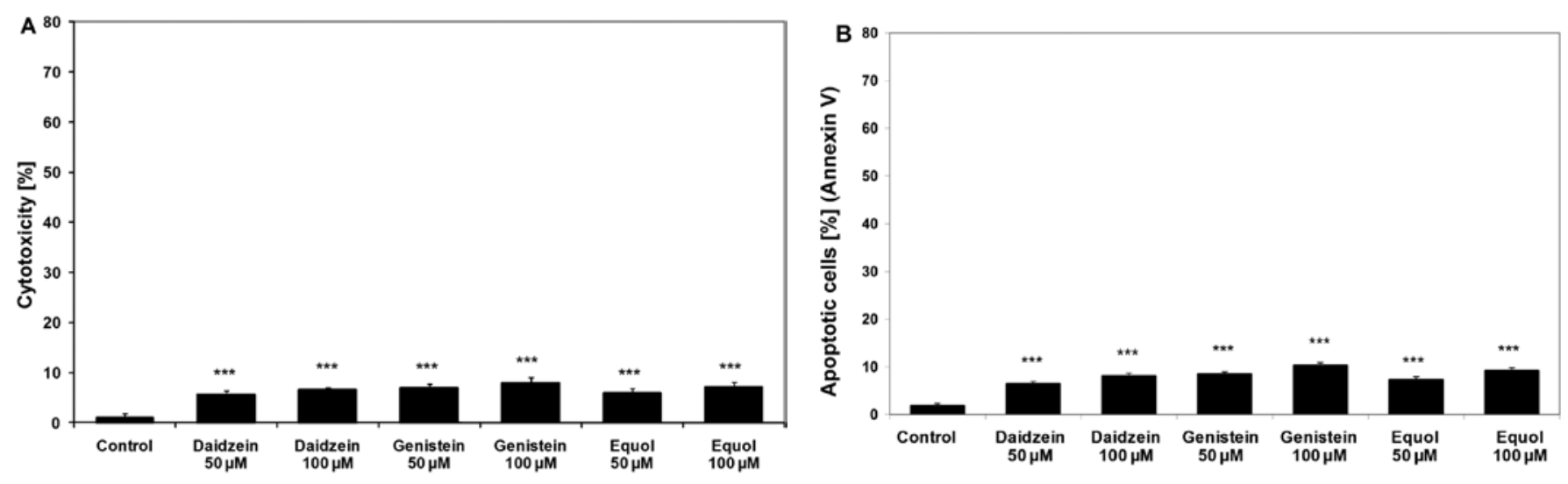

Figure 3. Cytotoxic and apoptotic effects of soy isoflavones in LNCaP prostate cancer cells. Cells were incubated for $48 \mathrm{~h}$ with isoflavones at concentrations of 50-100 $\mu \mathrm{M}$. (A) Cytotoxic activity of soy isoflavones in LNCaP cells. The percentage of dead cells was measured by the MTT cytotoxicity assay. The values represent the mean $\pm \mathrm{SD}$ of three independent experiments performed in quadruplicate $(n=12)\left({ }^{* * *} \mathrm{P}<0.001\right.$ as compared to control). (B) Apoptotic activity of soy isoflavones in LNCaP cells. Apoptotic cell death was detected by Annexin V-FITC staining using flow cytometry. The values represent the mean \pm SD of three independent experiments performed in duplicate $(n=6)\left({ }^{* * *} \mathrm{P}<0.001\right.$ as compared to control).

determined by Annexin V staining. A 48-h exposure to TRAIL at concentrations ranging from 50 to $100 \mathrm{ng} / \mathrm{ml}$ increased the percentage of apoptotic cells from $10.83 \pm 0.87$ to $21.29 \pm 0.77 \%$, respectively (Fig. 2B). TRAIL concentrations $>100 \mathrm{ng} / \mathrm{ml}$ resulted in no further significant increase in cell death. The studies showed that TRAIL was less active against the tested prostate cancer cell line and confirmed the resistance of LNCaP cells to TRAIL-mediated apoptosis and cytotoxicity.

Cytotoxic and apoptotic effects of soy isoflavones in prostate cancer cells. The prostate cancer cells were incubated for $48 \mathrm{~h}$ with isoflavones at concentrations of 50-100 $\mu \mathrm{M}$. We demonstrated that treatment of LNCaP cells with these compounds inhibited cell proliferation by inducing cytotoxicity and apoptosis in a dose-dependent manner. The cytotoxic effect of the isoflavones on LNCaP cells resulted in cell death from $5.67 \pm 0.73$ to $7.92 \pm 1.10 \%$, respectively, after treatment with concentrations of the isoflavones of 50-100 $\mu \mathrm{M}$ (Fig. 3A). The percentage of necrotic cell death of the cancer cells examined by Apoptest-FITC and the LDH assay was approximately zero. The Annexin V assay revealed apoptotic cells exposed to isoflavones (Fig. 3B). Incubation of prostate cancer cells with the soy isoflavones induced $6.46 \pm 0.48$ to $8.13 \pm 0.52 \%$ apoptosis for daidzein, $8.48 \pm 0.53$ to $10.32 \pm 0.61 \%$ apoptosis for genistein and $7.28 \pm 0.67$ to $9.23 \pm 0.58 \%$ apoptosis for equol, respective of the concentration of the isoflavone. These compounds exhibited low cytotoxic and apoptotic activities against LNCaP cells.

Cytotoxic and apoptotic effects of TRAIL in combination with soy isoflavones in prostate cancer cells. The co-treatment of LNCaP cells with TRAIL at concentrations of 50-100 ng/ml and isoflavones at the concentration of $100 \mu \mathrm{M}$ increased the percentage of cell death to a range from $38.21 \pm 0.72$ to $56.18 \pm 1.20 \%$ for daidzein, from $59.14 \pm 0.96$ to $70.55 \pm 0.99 \%$ for genistein and from $46.06 \pm 1.07$ to $60.35 \pm 1.04 \%$ for equol, respectively. The cytotoxicity measured by MTT assay is shown in Fig. 4A-C. The isoflavones augmented TRAILmediated apoptosis in the LNCaP cells. The percentage of apoptotic cells stained with Annexin V-FITC detected by flow cytometry after a 48-h exposure to at a concentration ranging from 50 to $100 \mathrm{ng} / \mathrm{ml}$ TRAIL with $100 \mu \mathrm{M}$ isoflavones was respectively elevated at a range from $41.60 \pm 0.50$ to $57.55 \pm 0.68 \%$ for daidzein, from $61.58 \pm 0.52$ to $71.38 \pm 0.76 \%$ for genistein and from $46.58 \pm 0.63$ to $62.05 \pm 1.19 \%$ for equol (Fig. 4D-F). The percentage of necrotic cell death of the LNCaP cells examined by Apoptest-FITC and LDH assay was approximately zero. Fluorescence microscopy used to visualize Annexin V-FITC staining confirmed that the isoflavones enhanced the apoptotic activity of TRAIL against prostate cancer cells (Fig. 4G-I). The soy isoflavones sensitized TRAIL-resistant LNCaP cells to TRAIL-mediated apoptosis.

Effects of soy isoflavones on death receptor expression in prostate cancer cells. The effects of soy isoflavones on the expression of TRAIL-R1 and TRAIL-R2 in LNCaP cells was examined by flow cytometry. The cancer cells were incubated for $48 \mathrm{~h}$ with isoflavones, and then assayed using PE-conjugated anti-TRAIL-R1 or anti-TRAIL-R2 antibodies. After treatment with daidzein, genistein or equol the expression of death receptors in the cancer cells did not change. The isoflavones did not increase the expression levels of TRAIL-R1 or TRAIL-R2 in the LNCaP cells (Fig. 5). To confirm these results, we used TRAIL-R1/Fc and TRAIL-R2/Fc chimera proteins, which have a dominant-negative function against TRAIL-R1 or TRAIL-R2, respectively. The chimeric proteins did not efficiently block apoptosis caused by the co-treatment of isoflavones and TRAIL.

Effects of TRAIL and soy isoflavones on mitochondrial membrane potential in prostate cancer cells. The loss of mitochondrial membrane potential $(\Delta \Psi \mathrm{m})$ has been shown to be one of the first intracellular changes following the onset of apoptosis. We examined whether soy isoflavones sensitize prostate cancer cells to TRAIL-induced mitochondrial dysfunction. Incubation of LNCaP cells with $100 \mathrm{ng} / \mathrm{ml}$ TRAIL or $100 \mu \mathrm{M}$ isoflavone (daidzein, genistein or equol) individually caused little effect on $\Delta \Psi_{\mathrm{m}}(7.63 \pm 0.75$ to $16.63 \pm 0.74 \%)$. Co-treatment of TRAIL and soy isoflavones resulted in a significantly synergistic enhancement of $\Delta \Psi \mathrm{m}$ disruption in a 

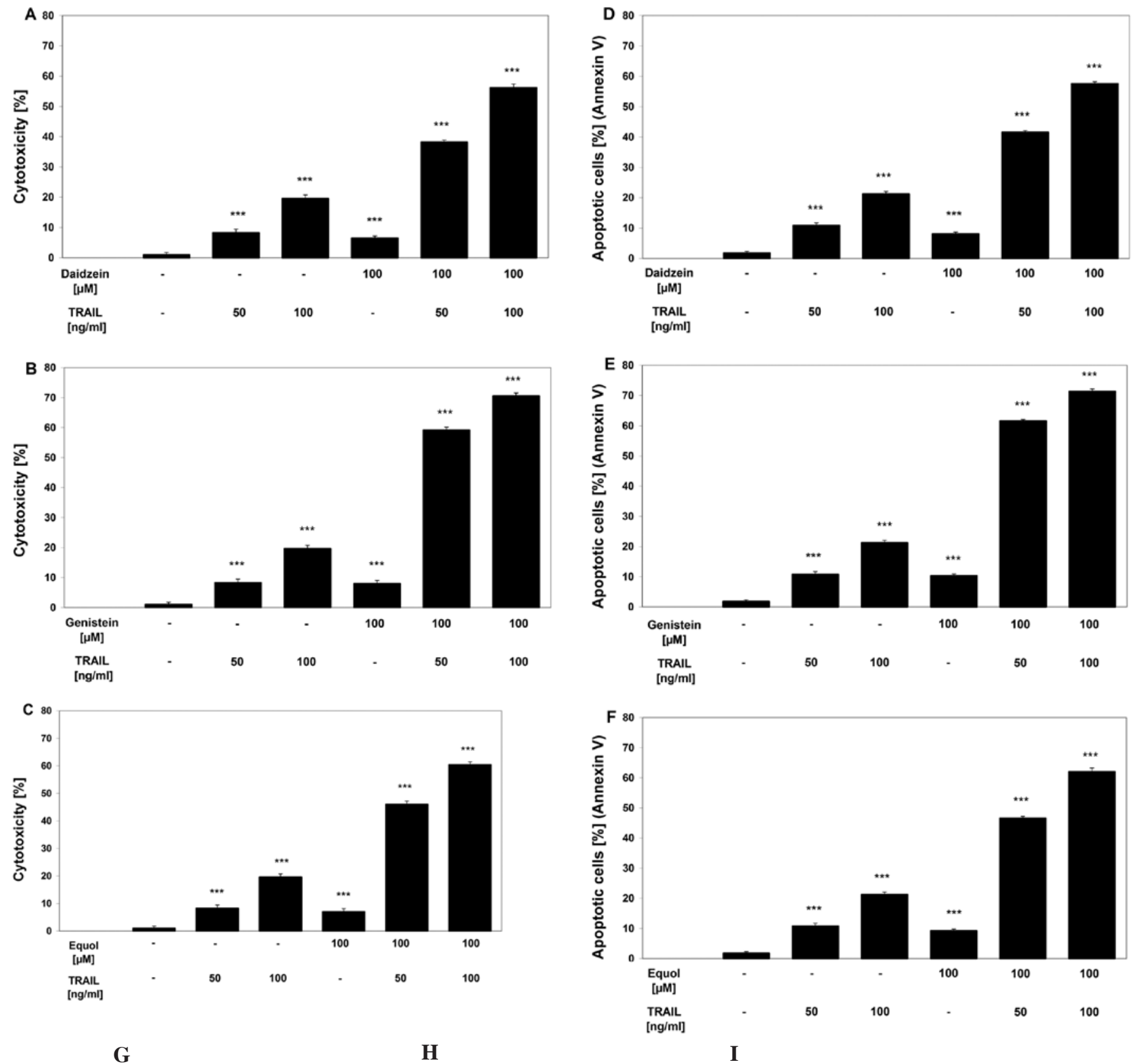

G

H

I
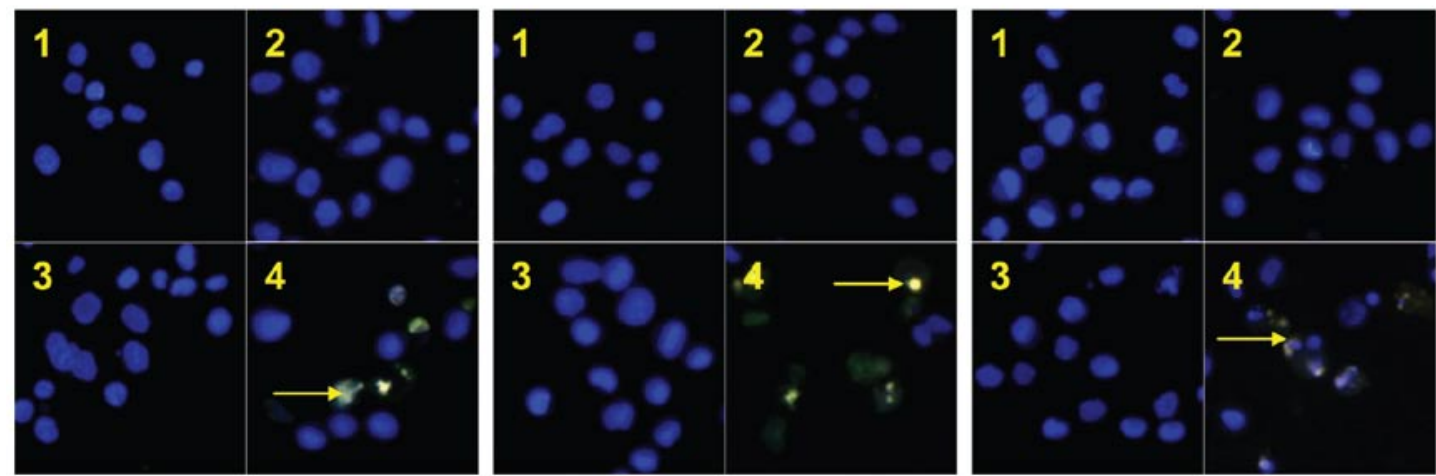

Figure 4. Cytotoxic and apoptotic effects of TRAIL in combination with soy isoflavones in LNCaP prostate cancer cells. Cells were incubated for $48 \mathrm{~h}$ with TRAIL at concentrations of 50-100 ng/ml and soy isoflavones at the concentration of $100 \mu \mathrm{M}$. Cytotoxic activity of TRAIL in combination with (A) daidzein, (B) genistein and (C) equol in LNCaP cells. The percentage of cell death was measured using the MTT cytotoxicity assay. The values represent mean \pm SD of

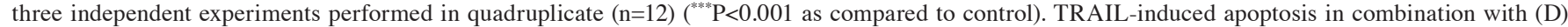
daidzein, (E) genistein and (F) equol in LNCaP cells. Apoptotic cell death was detected by flow cytometry using Annexin V-FITC staining. The values represent mean $\pm \mathrm{SD}$ of three independent experiments performed in duplicate $(\mathrm{n}=6)\left({ }^{* * * *} \mathrm{P}<0.001\right.$ as compared to control). TRAIL-induced apoptosis in combination with (G) daidzein, (H) genistein and (I) equol in LNCaP cells: (1) control cells, (2) cells incubated with TRAIL (100 ng/ml), (3) cells incubated with isoflavone $(100 \mu \mathrm{M})$, and 4) cells incubated with both TRAIL $(100 \mathrm{ng} / \mathrm{ml})$ and isoflavone $(100 \mu \mathrm{M})$. Apoptotic cell death was detected and visualized by fluorescence microscopy using Annexin V-FITC staining. Healthy cells (stained with Hoechst 33342) emitted blue fluorescence, and apoptotic cells (stained with Hoechst 33342 and Annexin V- FITC) emitted green and blue fluorescence (arrows). 
A
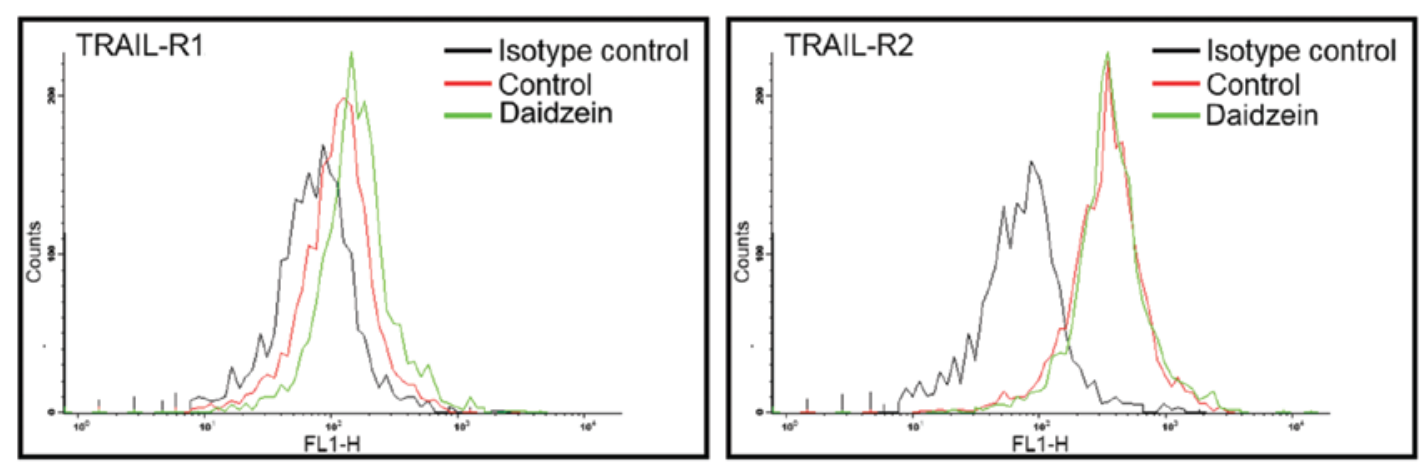

B
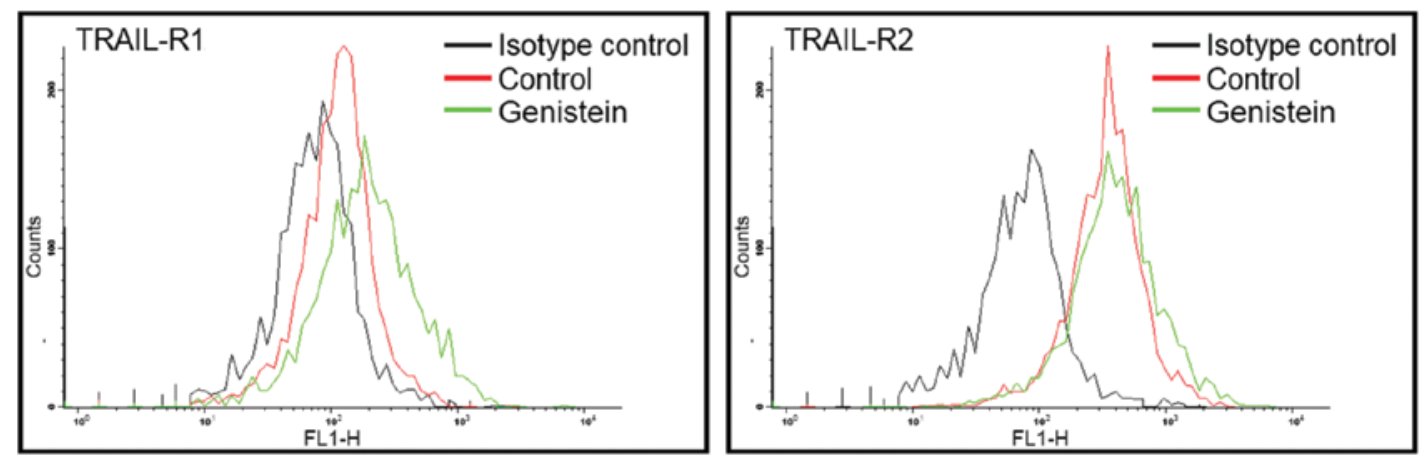

C
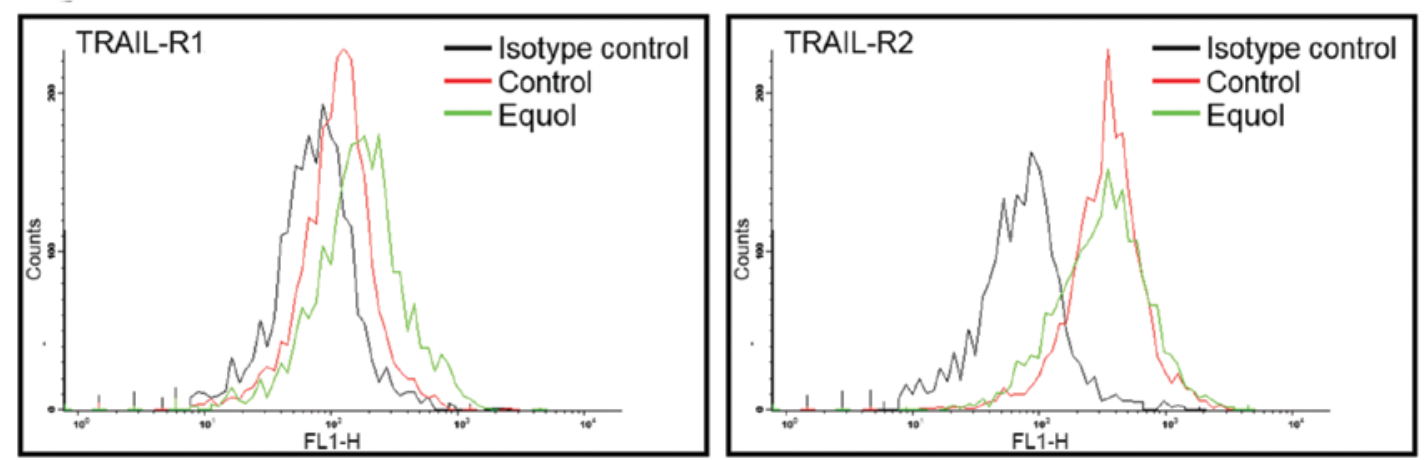

Figure 5. Effects of soy isoflavones on death receptor expression in LNCaP prostate cancer cells. Cells were incubated for $48 \mathrm{~h}$ with (A) daidzein, (B) genistein and (C) equol at a concentration of $100 \mu \mathrm{M}$. The surface expression of TRAIL-R1 (DR4) and TRAIL-R2 death receptors on LNCaP cells was measured by flow cytometric analysis. Representative histograms depict the average mean fluorescence from three independent experiments performed in duplicate $\mathrm{n}=6$.

large percentage of cancer cells $(53.38 \pm 1.41 \%$ for daidzein, $66.50 \pm 0.93 \%$ for genistein and $57.63 \pm 0.92 \%$ for equol) (Fig. 6). These results indicate the involvement of the mitochondrial (intrinsic) pathway in cancer cells treated simultaneously with TRAIL and isoflavones.

\section{Discussion}

Diets rich in soy products have been associated with reduced incidence and mortality of prostate cancer. Epidemiological evidence, together with preclinical data from animal and in vitro studies, strongly support a correlation between soy isoflavone consumption and protection against prostate cancer (4-10). These effects are mediated through the regulation of cell growth, cell cycle, apoptosis, angiogenesis, invasion and metastatic pathways. Isoflavones have been found to inhibit growth and induce apoptosis in LNCaP, DU145 and PC3 prostate cancer cells $(3,20,40)$. Soy isoflavone-supplemented diets were found to prevent the development of adenocarcinomas in prostate and seminal vesicles in a rat carcinogenesis model (41). In addition a soy diet reduced the growth of transplantable prostate adenocarcinomas and inhibited tumour cell proliferation and angiogenesis of transplantable prostate cancer in immunodeficient mice $(42,43)$.

Dysregulated apoptotic pathways play an important role in the initiation and progression of prostate cancer $(18,44,45)$. Data accumulated from in vitro and in vivo studies suggest that TRAIL plays an important role in the maintenance of immune homeostasis, host tumour surveillance and defense against cancer cells. We demonstrated that the soy isoflavones, daidzein, genistein and equol, markedly augmented TRAILinduced apoptosis in LNCaP cells. Similarly, other dietary agents may also enhance the apoptotic activity of TRAIL against prostate cancer cells. Epigallocatechin-3-gallate 

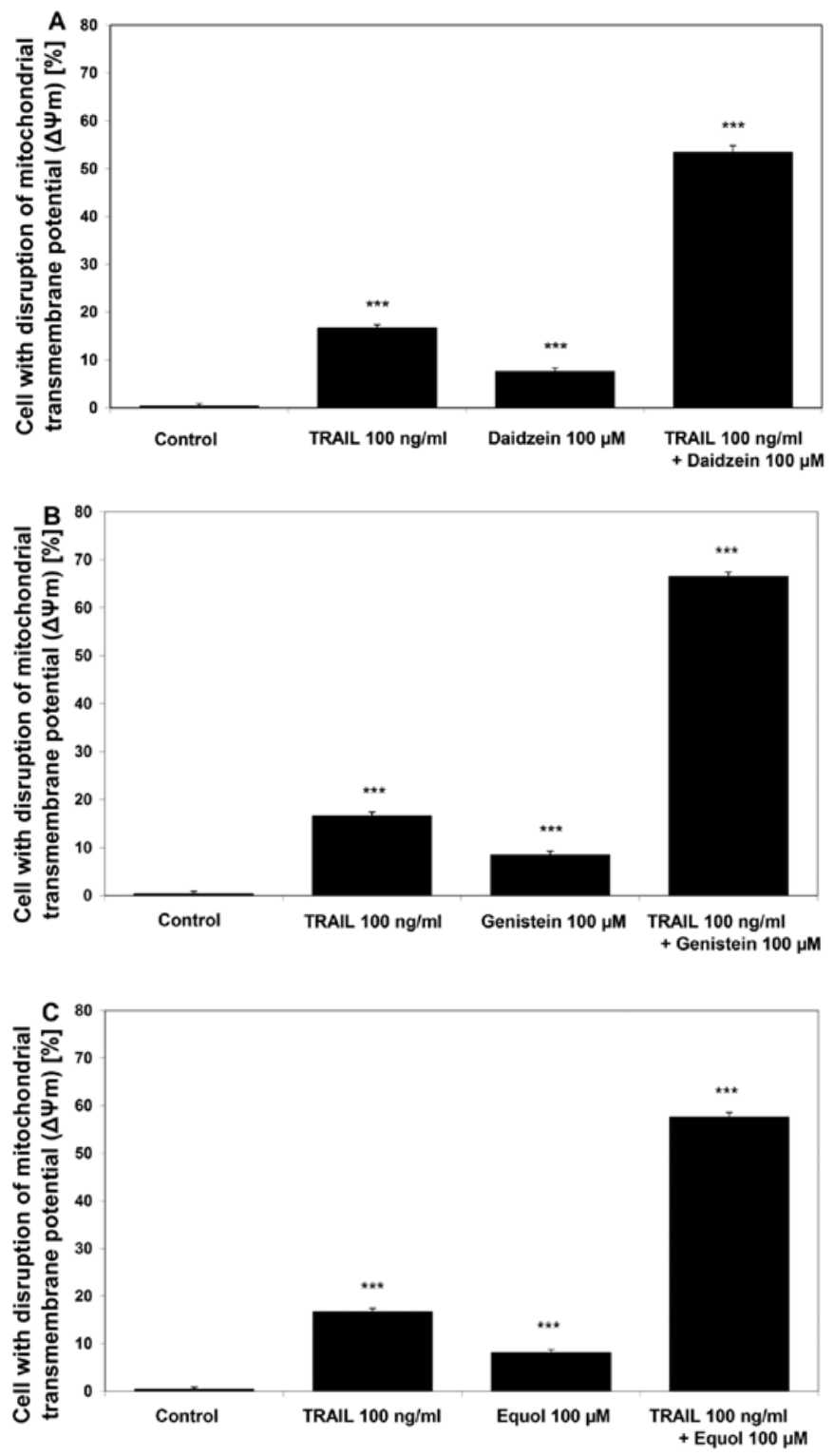

D

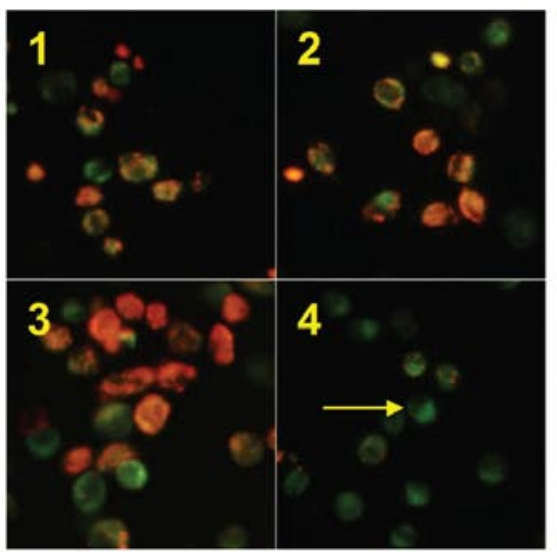

$\mathbf{E}$

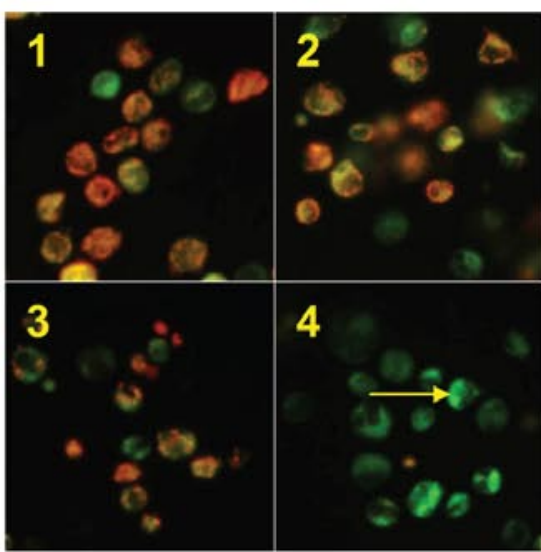

$\mathbf{F}$

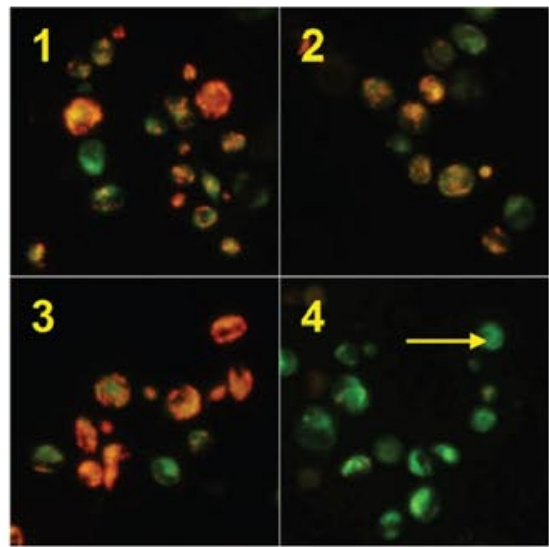

Figure 6. Effects of TRAIL in combination with the soy isoflavones on the mitochondrial membrane potential $(\Delta \Psi \mathrm{m})$ in LNCaP prostate cancer cells. Cells were incubated for $48 \mathrm{~h}$ with TRAIL at a concentration of $100 \mathrm{ng} / \mathrm{ml}$ and (A) daidzein, (B) genistein, (C) equol at a concentration of $100 \mu \mathrm{M}$. The values represent the mean $\pm \mathrm{SD}$ of three independent experiments performed in duplicate $(\mathrm{n}=6)\left({ }^{* * *} \mathrm{P}<0.001\right.$ as compared to control). (D-F). TRAIL in combination with isoflavones, (D) daidzein, (E) genistein and (F) equol, induced loss of $\Delta \Psi \mathrm{m}$ in LNCaP cells. Disruption of $\Delta \Psi \mathrm{m}$ in cancer cells was assessed by fluorescence microscopic analysis of DePsipher staining: (1) control cells, (2) cells incubated with TRAIL (100 ng/ml), (3) cells incubated with isoflavone $(100 \mu \mathrm{M})$, and 4) cells incubated with both TRAIL $(100 \mathrm{ng} / \mathrm{ml})$ and isoflavone $(100 \mu \mathrm{M})$. Red fluorescence is emitted from the red aggregates of the DePsipher, which are formed within the mitochondria in healthy cells. Green fluorescence reveals the monomeric form of the DePsipher molecule, which appears in the cytosol after mitochondrial membrane depolarization (arrows). 
(EGCG), the main green tea polyphenol, was found to abrogate TRAIL-resistance in LNCaP cells via the upregulation of TRAIL-R1 receptor and decrease in the $\Delta \Psi \mathrm{m}$ in $\mathrm{LNCaP}$ prostate cancer cells (46). Resveratrol, found in red wine, was found to sensitize TRAIL-resistant LNCaP cells through increased expression of TRAIL-R1 and TRAIL-R2 receptors, regulation of $\mathrm{Bcl}-2$ family protein expression, caspase activation and loss of $\Delta \Psi \mathrm{m}(47,48)$. Curcumin, the active component of the spice turmeric, which is derived from the rhizome of Curcuma longa, upregulated TRAIL-R1 and TRAIL-R2 receptor levels, activated caspases, inhibited $\mathrm{NF}-\kappa \mathrm{B}$ expression and modulated $\mathrm{Bcl}-2$ family proteins thus enhancing TRAILmediated apoptotic death in LNCaP cells (49).

Our results revealed that combined treatment of $\mathrm{LNCaP}$ cells with TRAIL and soy isoflavones induced mitochondrialdependent apoptosis, while soy isoflavones did not alter death receptor expression in LNCaP cells. Similar studies have described the synergistic apoptotic effects of TRAIL with daidzein or genistein on tumour cells. Daidzein was found to decrease the expression of the anti-apoptotic protein Bcl-2 and abolish resistance to TRAIL in LN229 glioblastoma cells (50). Genistein was demonstrated to augment TRAIL-mediated apoptosis through the downregulation of anti-apoptotic proteins, Akt and Bcl-xL in A549 lung cancer cells, downregulation of anti-apoptotic protein FLIP in LN229 glioblastoma cells, activation of casapase-3 in AsPC1 pancreatic and AGS gastric cancer cells, inhibition of p38 mitogen-activated protein kinase signalling and the decrease in expression of extracellular signal-regulated kinase ERK1/2 and protein Bcl-2 in HeLa cervical cancer cells (51-56). Our studies suggest that genistein, daidzein and equol exert TRAIL-mediated apoptotic effects at the level of the mitochondria. Co-treatment of LNCaP cells with TRAIL and isoflavones induced significant disruption of $\Delta \Psi \mathrm{m}$, compared to each of these agents alone. Jin et al described the reversal of TRAIL-resistance in Hep3B hepatocellular cancer cells by genistein via cleavage of Bid. Silencing of Bid expression reduced the decrease of $\Delta \Psi \mathrm{m}$ and blocked apoptosis in cancer cells treated with genistein and TRAIL (57). Baxa et al showed that genistein produced mitochondrial depolarization in the induction of apoptosis in murine T cells derived from thymic lymphomas (58). Moreover, Jin et al demonstrated that daidzein-mediated apoptosis in MCF7 breast cancer cells was accompanied by loss of $\Delta \Psi \mathrm{m}$ and regulation of $\mathrm{Bcl}-2$ family proteins (59).

These in vitro and in vivo tests have demonstrated the potential of natural polyphenols to enhance TRAIL-mediated apoptotic death in cancer (60). We showed for the first time that daidzein, genistein and equol sensitized TRAIL-resistant LNCaP prostate cancer cells, but further investigation is required to further elucidate the related cellular signalling pathways. Our study confirms the hypothesis that the chemopreventive effects of isoflavones in soy foods or soy supplements are associated with the enhancement of TRAIL-induced apoptosis in prostate cancer cells.

\section{Acknowledgements}

This project was supported by the research grant KNW-1087/10 from the Medical University of Silesia in Katowice, Poland.

\section{References}

1. Crawford ED: Understanding the epidemiology, natural history, and key pathways involved in prostate cancer. Urology 73: 4-10, 2009.

2. Venkateswaran V and Klotz LH: Diet and prostate cancer: mechanisms of action and implications for chemoprevention. Nat Rev Urol 7: 442-453, 2010.

3. Sarkar FH and Li Y: Soy isoflavones and cancer prevention. Cancer Invest 21: 744-757, 2003.

4. Hwang YW, Kim SY, Jee SH, Kim YN and Nam CM: Soy food consumption and risk of prostate cancer: a meta analysis of observational studies. Nutr Cancer 61: 598-606, 2009.

5. Jian L: Soy, isoflavones, and prostate cancer. Mol Nutr Food Res 53: 217-226, 2009.

6. Gardner CD, Oelrich B, Liu JP, Feldman D, Franke AA and Brooks JD: Prostatic soy isoflavone concentrations exceed serum levels after dietary supplementation. Prostate 69: 719-726, 2009.

7. Souza PL, Russel PJ, Kearsley JH and Howes LG: Clinical pharmacology of isoflavones and its relevance for potential of prostate cancer. Nutr Rev 68: 542-555, 2010.

8. Perabo FGE, Von Low EC, Ellinger J, Von Rucker A, Muller SC and Bastian PJ: Soy isoflavone genistein in prevention and treatment of prostate cancer. Prostate Cancer Prostatic Dis 11: 6-12, 2005

9. Xiao CW: Health effects of soy protein and isoflavones in humans. J Nutr 136: 1244-1249, 2008.

10. Taylor CK, Levy RM, Elliott JC and Burnett BP: The effect of genistein aglycone on cancer and cancer risk: a review of in vitro, preclinical, and clinical studies. Nutr Rev 67: 398-415, 2009.

11. Delmonte P and Rader JI: Analysis of isoflavones in food and dietary supplements. J AOAC Int 89: 1138-1146, 2006.

12. Ramos S: Effects of dietary flavonoids on apoptotic pathways related to cancer chemoprevention. J Nutr Biochem 18: 427-442, 2007.

13. Ishihara M, Naoi K, Hashita M, Itoh Y and Suzui M: Growth inhibitory activity of ethanol extracts of Chinese and Brazilian propolis in four human colon carcinoma cell lines. Oncol Rep 22: 349-354, 2009

14. Androutsopoulos VP, Ruparelia K, Aroo RRJ, Tsatsakis AM and Spandidos DA: CYP-1-mediated antiproliferative activity of dietary flavonoids in MDA-MB-468 breast cancer cells. Toxicology 264: 162-170, 2009.

15. Androutsopoulos VP,Papakyriakou A, Vourloumis D, Tsatsakis AM and Spandidos DA: Dietary flavonoids in cancer therapy and prevention: substrates and inhibitors of cytochrome P450 CYP1 enzymes. Pharmacol Ther 126: 9-20, 2010.

16. Phutthaphadoong S, Yamada Y, Hirata A, Tomita H, Hara A, Limtrakul P, Iwasaki T, Kobayashi $\mathrm{H}$ and Mori H: Chemopreventive effect of fermed brown rice and rice bran (FBRA) on the inflammation-related colorectal carcinogenesis in $A p c^{\mathrm{Min} /+}$ mice. Oncol Rep 23: 53-59, 2010.

17. Wang LG and Chiao JW: Prostate cancer chemoprevention activity of phenethyl isothiocyanate through epigenetic regulation (Review). Int J Oncol 37: 533-539, 2010.

18. Khan N, Adhami VM and Mukhtar H: Apoptosis by dietary agents for prevention and treatment of prostate cancer. Endocr Relat Cancer 17: 39-52, 2010.

19. Sarkar FH, Li Y, Wang Z and Kong D: Novel targets for prostate cancer chemoprevention. Endocr Relat Cancer 17: 195-212, 2010.

20. Banerjee S, Li Y, Wang Z and Sarkar FH: Multi-targeted therapy of cancer by genistein. Cancer Lett 269: 226-242, 2008.

21. Tanaguchi H, Yoshida T, Horinaka M, Yasuda T, Goda AE, Konishi M, Wakada M, Kataoka K, Yoshikawa T and Sakai T: Baicalein overcomes tumor necrosis factor-related apoptosisinducing ligand resistance via two different cell specific pathways in cancer cells but not in normal cells. Cancer Res 68: 8918-8927, 2008.

22. Szliszka E, Czuba ZP, Bronikowska J, Mertas A, Paradysz A and Krol W: Ethanolic extract of propolis (EEP) augments TRAILinduced apoptotic death in prostate cancer cells. Evid Based Complement Alternat Med: doi:10.1093/ecam/nep180, 2009.

23. Szliszka E, Czuba ZP, Mazur B, Sedek L, Paradysz A and Krol W: Chalcones enhance TRAIL-induced apoptosis in prostate cancer cells. Int J Mol Sci 11: 1-13, 2010.

24. Szliszka E, Czuba ZP, Mazur B, Paradysz A and Krol W: Chalcones and dihydrochalcones augment TRAIL-mediated apoptosis in prostate cancer cells. Molecules 15: 5336-5353, 2010. 
25. Almasan A and Ashkenazi A: Apo2L/TRAIL: apoptosis signaling, biology and potential for cancer therapy. Cytokine Growth Factor Rev 14: 337-348, 2003.

26. Büneker C, Mohr A and Zwacka RM: The TRAIL-receptor-1: TRAIL-receptor-3 and -4 ratio is a predictor for TRAIL sensitivity of cancer cells. Oncol Rep 21: 1289-1295, 2009.

27. Baritaki S, Huerta-Yepez S, Sakai T, Spandidos DA and Bonavida B: Chemotherapeutic drugs sensitize cancer cells to TRAIL-mediated apoptosis: up-regulation of DR5 and inhibition of Yin Yang 1. Mol Cancer Ther 6: 1387-1399, 2007.

28. Baritaki S, Suzuki E, Umezawa K, Spandidos DA, Berenson J, Daniels TR, Penichet ML, Jazirehi AR, Pallandino M and Bonavida B: Inhibition of Yin Yang 1-dependent repressor activity of DR5 transcription and expression by the novel proteasome inhibitor NPI-0052 contributes to its TRAIL-enhanced apoptosis in cancer cells. J Immunol 180: 6199-6210, 2008.

29. Basu A and Haldar S: Combinatorial effect of epigallocatechin-3gallate and TRAIL on pancreatic cell death. Int J Oncol 34: 281-286, 2009

30. Thorburn A, Behbakht K and Ford H: TRAIL receptor-targeted therapeutics: resistance mechanisms and strategies to avoid them. Drug Resist Updat 11: 17-24, 2008.

31. Lee SJ, Noh HJ, Sung EG, Song IH, Kim JY, Kwon TK and Lee TJ: Berberine sensitizes TRAIL-induced apoptosis through proteasome-mediated downregulation of c-FLIP and Mcl-1 proteins. Int J Oncol 38: 485-492, 2011.

32. Jakóbisiak M, Lasek W and Gołąb J: Natural mechanisms protecting against cancer. Immunol Lett 90: 103-122, 2003.

33. Szliszka E, Bronikowska J, Majcher A, Miszkiewicz J and Krol W: Enhanced sensitivity of hormone-refractory prostate cancer cells to tumor necrosis factor-related apoptosis-inducing ligand (TRAIL) mediated cytotoxicity by taxanes. CEJ Urol 62 : 29-34, 2009.

34. Szliszka E, Czuba ZP, Jernas K and Krol W: Dietary flavonoids sensitize HeLa cells to tumor necrosis factor-related apoptosisinducing ligand (TRAIL). Int J Mol Sci 9: 56-64, 2008.

35. Szliszka E, Czuba ZP, Domino M, Mazur B, Zydowicz G and Krol W: Ethanolic extract of propolis (EEP) enhances the apoptosis-inducing potential of TRAIL in cancer cells. Molecules 14: 738-754, 2009

36. Bronikowska J, Szliszka E, Czuba ZP, Zwolinski D, Szmydki B and Krol W: The combination of TRAIL and isoflavones enhances apoptosis in cancer cells. Molecules 15: 2000-2015, 2010.

37. Szliszka E, Czuba ZP, Sedek L, Paradysz A and Krol W: Enhanced TRAIL-mediated apoptosis in prostate cancer cells by the bioactive compounds neobavaisoflavone and psoralidin isolated from Psoralea corylifolia. Pharmacol Rep 63: 139-148, 2011.

38. Szliszka E, Zydowicz G, Janoszka B, Dobosz C, KowalczykZiomek G and Krol W: Ethanolic extract of Brazilian green propolis sensitizes prostate cancer cells to TRAIL-induced apoptosis. Int J Oncol 38: 941-953, 2011.

39. Szliszka E, Mazur B, Zydowicz G, Czuba ZP and Krol W: TRAIL-induced apoptosis and expression of death receptor TRAIL-R1 and TRAIL-R2 in bladder cancer cells. Folia Histochem Cytobiol 47: 579-585, 2009.

40. Ping SY, Hour TC, Lin SR and Yu DS: Taxol synergizes with antioxidants in inhibiting hormonal refractory prostate cancer cell growth. Urol Oncol 28: 170-179, 2010.

41. Onozawa M, Kawamori T, Baba M, Fakuda K, Toda T, Sato H, Ohtani M, Akaza H, Sugimura T and Wakabayashi K: Effects of soybean isoflavone mixture on carcinogenesis in prostate and seminal vesicles of F344 rats. Jpn J Cancer Res 90: 393-398, 1999.

42. Landstrom M, Zhang JX, Hallmans G, Aman P, Bergh A Damber JE, Mazur W, Wahala K and Adlercreutz H: Inhibitory effects of soy and rye diets on development of Dunning R3327 prostate adenocarcinomas in rats. Prostate 36: 151-161, 1998

43. Zhou JR, Gugger ET, Tanaka T, Guo Y, Blackburn GL and Clinton SK: Soybean phytochemicals inhibit the growth of transplantable human prostate carcinoma and tumor angiogenesis in mice. J Nutr 129: 1628-1635, 1999.
44. Soulitzis N, Karyotis I, Delakas D and Spandidos DA: Expression analysis of peptide growth factors VEGF, FGF2, TGFB1, EGF and IGF1 in prostate cancer and benign prostatic hyperplasia. Int J Oncol 29: 305-314, 2006

45. Ku JH, Seo SY, Kwak C and Kim HH: The role of survivin and Bcl-2 in zinc-induced apoptosis in prostate cancer cells. Urol Oncol: doi:10.1016/j.urolonc.2010.06.001, 2010.

46. Siddqui IA, Malik A, Adhami VM, Asim M, Hafeez BB, Sarfaraz S and Mukhtar H: Green tea polyphenol EGCG sensitizes human prostate carcinoma LNCaP cells to TRAILmediated apoptosis and synergistically inhibits biomarkers associated with angiogenesis and metastasis. Oncogene 27: 2055-2063, 2008.

47. Fulda S and Debatin KM: Resveratrol-mediated sensitization to TRAIL-induced apoptosis depends on death receptor and mitochondrial signaling. Eur J Cancer 41: 786-798, 2005.

48. Shankar S, Chen Q, Siddiqui I, Sarva K and Srivastava RK: Sensitization of TRAIL-resistant LNCaP cells by resveratrol (3,4',5-trihydroxystilbene): molecular mechanisms and therapeutic potential. J Mol Signal 2: 27-36, 2007.

49. Shankar S, Chen Q, Sarva K, Siddiqui I and Srivastava RK: Curcumin enhances the apoptosis-inducing potential of TRAIL in prostate cancer: molecular mechanisms of apoptosis, migration and angiogenesis. J Mol Signal 2: 1-14, 2007.

50. Siegelin MD, Gaiser T, Habel A and Siegelin Y: Daidzein overcomes TRAIL-resistance in malignant glioma cells by modulating the expression of the intrinsic apoptotic inhibitor, bcl-2. Neurosci Lett 454: 223-228, 2009

51. Park SY and Seol DW: Regulation of Akt by EGF-R inhibitors, a possible mechanism of EGF-R inhibitor enhanced TRAILinduced apoptosis. Biochem Biophys Res Commun 295: 515-518, 2002.

52. Nozawa F, Itami A, Saruc M, Kim M, Standop J, Picha KS, Cowan KH and Pour PM: The combination of tumor necrosis factor-related apoptosis-inducing ligand (TRAIL/Apo2L) and genistein is effective in inhibiting pancreatic cancer growth. Pancreas 29: 45-52, 2004.

53. Lee MW, Bach JH, Lee DY, Joo WS, Kim KY, Lee WB and Kim SS: The activation of ERK1/2 via a tyrosine kinase pathway attenuates TRAIL-induced apoptosis in HeLa cells. Cancer Invest 23: 586-592, 2005.

54. Jin CY, Park C, Cheong J, Choi BT, Lee TH, Lee JD, Lee WH, Kim GY, Ryu CH and Choi YH: Genistein sensitizes TRAILresistant human gastric adenocarcinoma AGS cells through activation of caspase-3. Cancer Lett 257: 56-64, 2007.

55. Jin CY, Park C, Kim GY, Lee SJ, Kim WJ and Choi YH Genistein enhances TRAIL-induced apoptosis through inhibition of p38 MAPK signaling in human hepatocellular carcinoma Hep3B cells. Chem Biol Interact 180: 143-150, 2009.

56. Siegelin MD, Siegelin Y, Habel A and Gaiser T: Genistein enhances proteosomal degradation of the short isoform of FLIP in malignant glioma cells and thereby augments TRAIL-mediated apoptosis. Neurosci Lett 453: 92-97, 2009.

57. Jin CY, Park C, Moon SK, Kim GY, Kwon TK, Lee SJ, Kim WJ and Choi YH: Genistein sensitizes human hepatocellular carcinoma cells to TRAIL-mediated apoptosis by enhancing Bid cleavage. Anticancer Drugs 20: 713-722, 2009.

58. Baxa DM, Luo X and Yoshimura FK: Genistein induces apoptosis in T lymphoma cells via mitochondrial damage. Nutr Cancer 51: 93-101, 2005.

59. Jin S, Zhang QY, Kang XM, Wang JX and Zhao WH: Daidzein induces MCF-7 breast cancer cell apoptosis via mitochondrial pathway. Ann Oncol 21: 263-268, 2010.

60. Szliszka E and Krol W: The role of dietary polyphenols in tumor necrosis factor-related apoptosis inducing ligand (TRAIL)induced apoptosis for cancer chemoprevention. Eur J Cancer Prev 20: 63-69, 2011. 